\title{
Mean Lipid Profile among Patients Suffering from Oral Sub-mucous Fibrosis reporting in a Tertiary Care Hospital of Karachi, Pakistan: A Descriptive Study
}

\author{
Maimoona Siddiq1, Junaid Shakeel ${ }^{2}$, Syed Mahmood Haider ${ }^{3}$, Sana Siddiq ${ }^{4}$
}

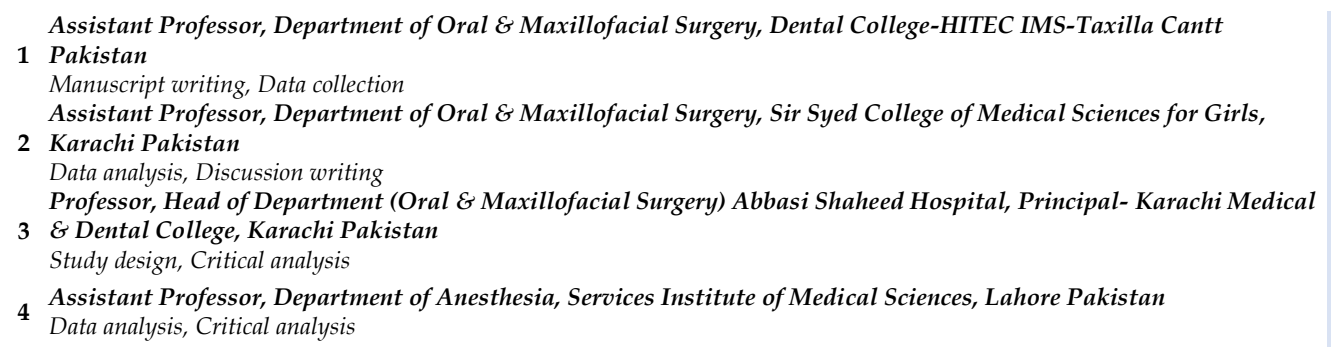

CORRESPONDING AUTHOR

Dr. Maimoona Siddiq

Assistant Professor, Maxillofacial Surgery, Dental

College-HITEC IMS, Taxilla Cantt Pakistan

Email: the_dentist007@hotmail.com

Submitted for Publication: 28-12-2020 Accepted for Publication 12-03-2021

How to Cite: Siddiq M, Shakeel J, Haider SM, Siddiq S. Mean Lipid Profile among Patients Suffering from Oral Sub-mucous Fibrosis Reporting in a Tertiary Care Hospital of Karachi, Pakistan: A Descriptive Study. APMC 2021;15(1):12-6. DOI: 10.29054/APMC/2021.1132

\section{ABSTRACT}

Background: Oral Submucous Fibrosis is a potent pre-malignant condition of Oral cavity, which is prevalent in South Asian countries, due to social habit of pan, gutka, areca nut and betel quid chewing, which is mostly practiced in South-East Asia. A decreased pattern of lipid profile has been observed in literature in many precancerous conditions, this study is based on observation of lipid profile pattern among Oral submucous fibrosis patients in relation with age, gender, body mass index and duration of disease. Objective: A descriptive study to determine mean lipid profile values among oral sub-mucous fibrosis patients. Study Design: Descriptive (cross-sectional) study. Settings: Department of Oral \& Maxillofacial Surgery, Abbasi Shaheed Hospital-Karachi Pakistan. Duration: 1st January 2017 till 30 th June 2017, for a period of six months. Methodology: Oral Sub-mucous Fibrosis (OSMF) patients, who also met with inclusion criteria of study were selected. Lipid Profile values of TC (total cholesterol), HDL (high density lipids), LDL (low density lipids) and triglycerides were observed among OSMF patients in relation to duration of disease, their different age groups, gender and body mass index (BMI). Results: Out of 104 clinically diagnosed patients of OSMF, 34 females and 70 were males. Mean age was 38.9, most of the patients were in the age group of 20-40 years. Mean and standard deviation of TC, triglycerides, LDL and HDL was $132.19 \pm 13.29,142.25 \pm 8.71,101.87 \pm 17.57$ and $30.43 \pm 2.56$ respectively. Conclusion: Results of this study revealed that there is no significant change in pattern of lipid profile among OSMF patients in relation to their different age groups, gender and BMI, but an inverse relation does exist between lipid panel and duration of disease.

Keywords: Oral submucous fibrosis, Oral pre-malignant condition, Lipid profile Areca nut, Mottled oral mucosa.

\section{INTRODUCTION}

Oral sub-mucous fibrosis (OSMF) is an enfeebling oral pathology and a potential pre-malignant condition. An observational study demonstrated its malignant transformation rate of $7.6 \%^{1}$ over period of 17 years. The disease is more prevalent among males, younger age group from 15-34 years are at highest risk of disease. According to a study ${ }^{2}$ of 6800 people, $73.5 \%$ were males, and $26.5 \%$ were females suffering from the disease. This precancerous condition is potentially associated with pan, gutka, areca nut and betel quid chewing, which is mostly practiced in South-East Asia. ${ }^{1,3}$

OSMF presents with progressive fibrosis of oral submucosal tissue, leading to limited mouth opening, oral mucosal changes, fibrous bands in oral cavity buccal and labial mucosa along with tonsillar pillars, resulting in leathery and mottled oral mucosa. ${ }^{3}$
As Lipids are major cell membrane components, they are essential for cellular integrity, growth and proliferation. Thus, there is a strong association of change in lipid profile with cancerous and precancerous conditions.

Studies ${ }^{4,5,7}$ show an inverse change of TCL, HDL, LDL and Serum Triglyceride levels in patients with oral submucous fibrosis when compared with control group.

Less literature is present, and very few studies are conducted on lipid profile change in oral pre-malignant conditions. Inverse pattern of lipid profile may be due to their increased consumption in cellular proliferation or due to unknown etiology. 4

Few Literature is available on pattern of lipid profile among OSMF patients in which lipid profile is observed in relation with mouth opening and disease stage, ${ }^{5}$ extensive research revealed that there is lack of present literature about lipid profile pattern among OSMF 
patients in relation with age, gender, duration of disease and BMI, which makes this study unique.

Evaluation of lipid profile of these patients is essential to determine its actual proportional relation either positive or negative within the disease itself, it may become helpful in future research for early diagnosis of malignant potential of the disease and may help in the diagnosis of disease condition at the biochemical level.

Aim of this study is to evaluate lipid profile in oral submucous fibrosis (OSMF) patients and its pattern among various age groups, gender, BMI and duration of disease, which may be helpful to determine the severity of disease at biochemical level in relation with these above mentioned variables, which has a prognostic and diagnostic significance.

This study is an attempt to observe the pattern of lipid profile among OSMF patients.

Extensive research and study on this topic may reveal interesting facts about the mean lipid profile values in pre-malignant states. ${ }^{4-6}$

\section{METHODOLOGY}

Study Design: Descriptive cross-sectional study.

Settings: Department of Oral and Maxillofacial Surgery, Abbasi Shaheed hospital, Karachi Pakistan.

Duration: Six months, from January 01, 2017 to June 30 2017.

Sample Technique: Non-probability (Consecutive sampling).

Sample Size: The sample size was calculated by using the World Health Organization sample size calculator mean \pm SD of serum triglycerides ${ }^{4}=87.07 \pm 33.82$ $\mathrm{d}=6.5$

$1-\alpha=95 \%$

Sample size calculated $=\mathrm{n}=104$ patients

Inclusion Criteria: Male and female patients, $1^{\text {st }}$ time clinically diagnosed with oral sub-mucous fibrosis from OPD of Abbasi Shaheed Hospital Karachi, between the age of 18 to 60 years were included in this study.

Exclusion Criteria: Subjects with a previous or present history of major illness (diabetes, hypertension, carcinoma, cardiovascular, liver or pancreatic disease), using lipid lowering drugs, Women who were pregnant or lactating or using oral contraceptives, Patients who were below or above the normal range of BMI, and patients below age of 18 or above 60 years were not included in study.

Data Collection Procedure: After approval from the Ethical Committee, Patients were selected from the OPD of Oral and Maxillofacial Surgery, Abbasi Shaheed Hospital. Informed consent was taken from all subjects. Fasting blood sample was drawn in plain vials for lipid profile and sent to the histopathology laboratory of the same hospital. Serum values of TC, HDL, LDL and triglycerides were filled in the proforma, specially designed for the study requirement.
Subjects with altered lipid profile due to reasons like, systemic illness, use of lipid-lowering drugs, those with increased or decreased BMI (body mass index) was considered as bias, which was controlled by careful patient assortment who met with inclusion criteria only. There is no control group in this study due to ethical reasons.

Data Analysis: Statistical package for social sciences SPSS-22 was used to analyze the data. P-value $<0.05$ was considered statistically significant and confidence interval of $95 \%$. Stratification was done in terms of age, gender, duration of disease and BMI. For quantitative variables, like TC, HDL, LDL, triglyceride, age, duration of disease and BMI, the mean and standard deviation was determined. Post-stratification t-test was applied to determine the relation of TC, HDL, LDL and triglycerides. Frequency and percentage was calculated for gender.

\section{RESULTS}

Out of 104 patients, the minimum age of the patient was 24 , while the maximum age of the patients was 52 years. Mean age in our study was 38.96 years with the standard deviation of \pm 7.64 . Mean duration of disease and BMI in this study were $1.58 \pm 0.64$ and $29.78 \pm 3.33$, respectively. Furthermore, values of mean cholesterol, triglyceride, LDL and HDL were 132.19 $\pm 13.29,142.25 \pm 8.71$, $101.87 \pm 17.57$ and $30.43 \pm 2.56$, respectively. As shown in Table 1. Which shows an inverse pattern if we compare with normal reference range ${ }^{24}$ of cholesterol, triglyceride, LDL and HDL which are up to $200 \mathrm{mg} / \mathrm{dl}$, up to 150 $\mathrm{mg} / \mathrm{dl}$, up to $100 \mathrm{mg} / \mathrm{dl}, 60 \mathrm{mg} / \mathrm{dl}$ or above respectively. Frequency distribution of gender and age showed $67.3 \%$ male and $32.7 \%$ were females, $56.7 \%$ and $43.3 \%$ were in age group 21-40 years and 41-60 years, respectively.

Frequency distribution of duration of disease and BMI showed $26 \%$ had the disease for less than 2 years and $74 \%$ had the disease for more than two years of duration while $43(41.3 \%)$ patients had BMI < 30 and $61(58.7 \%)$ patients had BMI $>30$ respectively.

Stratification for age with respect to lipid profile showed that mean cholesterol level was $132.56 \pm 12.89$ and $133.47 \pm 14.16$ in $21-40$ and $41-60$ years age group respectively. P value was 0.73 . Whereas mean triglyceride level was $142.26 \pm 8.85$ and $142.22 \pm 8.62$ in 21-40 and 41-60 years age group, respectively. $\mathrm{P}$ value was 0.84 . Moreover, mean LDL level was $104.20 \pm 18.08$ and $98.81 \pm 16.60$ in $21-40$ and $41-60$ years age group, respectively. P value was 0.11 . Finally, mean HDL level was $30.53 \pm 2.56$ and $30.29 \pm 2.59$ in $21-40$ and $41-60$ years age group respectively. P value was 0.63 . As presented in Table 2.

Stratification for gender with respect to lipid profile showed that mean cholesterol level was $133.39 \pm 11.86$ and $131.85 \pm 16.25$ in male and female gender respectively. $\mathrm{P}$ value was 0.56 . Whereas mean triglyceride level was 
$142.31 \pm 9.08$ and $142.76 \pm 8.01$ in male and female gender respectively. P value was 0.79 . Moreover, mean LDL level was $103.10 \pm 18.47$ and $99.34 \pm 15.53$ in male and female gender respectively. P value was 0.28 . Finally mean HDL level was $30.75 \pm 2.73$ and $29.77 \pm 2.07$ in male and female gender respectively. $\mathrm{P}$ value was 0.06 . As presented in Table 2 .

Stratification for duration of disease with respect to lipid profile showed that mean cholesterol level was $127.48 \pm 14.42$ and $134.87 \pm 12.56$ in duration of disease group of $>2$ years and $<2$ years respectively. P-value was 0.23 . Whereas mean triglyceride level was $139.70 \pm 7.39$ and $143.43 \pm 8.97$ in duration of disease group of $>2$ years and $<2$ years respectively. $\mathrm{P}$ value was 0.38 . Moreover, mean LDL level was $93.06 \pm 13.18$ and $104.96 \pm 17.94$ in duration of disease group of $>2$ years and $<2$ years respectively. P value was 0.02. Finally, mean HDL level was $29.58 \pm 2.90$ and $30.72 \pm 2.38$ in the duration of disease group of $>2$ years and $<2$ years respectively. P-value was 0.72 . As presented in Table 2.

Stratification for BMI status with respect to lipid profile showed that mean cholesterol level was $135.00 \pm 15.42$ and $131.51 \pm 11.69$ in BMI status group of $<30 \mathrm{~kg} / \mathrm{m}^{2}$ and $>30$ $\mathrm{kg} / \mathrm{m}^{2}$, respectively. $\mathrm{P}$ value was 0.21 . Whereas mean triglyceride level was $144.21 \pm 8.65$ and $141.23 \pm 8.61$ in BMI status group of $<30 \mathrm{~kg} / \mathrm{m}^{2}$ and $>30 \mathrm{~kg} / \mathrm{m}^{2}$ respectively. $P$ value was 0.08 . Moreover, mean LDL level was $102.42 \pm 12.74$ and $101.49 \pm 20.40$ in BMI status group of $<30$ $\mathrm{kg} / \mathrm{m}^{2}$ and $>30 \mathrm{~kg} / \mathrm{m}^{2}$, respectively. $\mathrm{P}$ value was 0.79 . Finally, mean HDL level was $30.77 \pm 2.10$ and $30.19 \pm 2.83$ in BMI status group of $<30 \mathrm{~kg} / \mathrm{m}^{2}$ and $>30 \mathrm{~kg} / \mathrm{m}^{2}$ respectively with a p-value 0.25 . As presented in Table 2 .

Figure 1: Duration of disease distribution

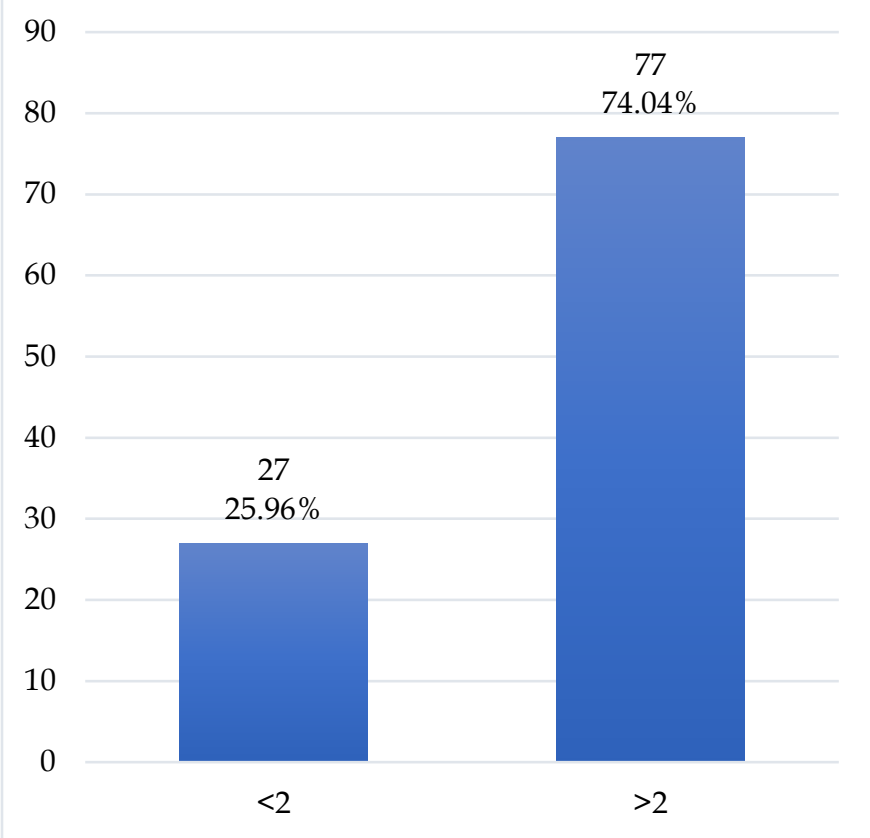

Figure 2: Age distribution

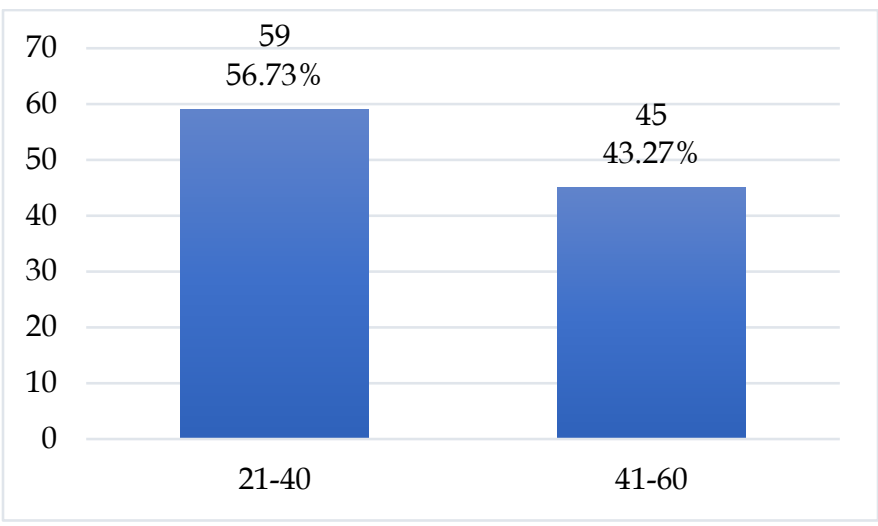

Figure 3: Gender distribution

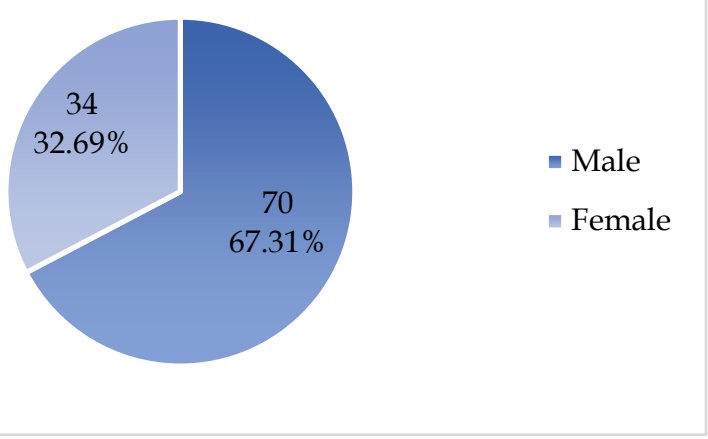

Figure 4: BMI distribution

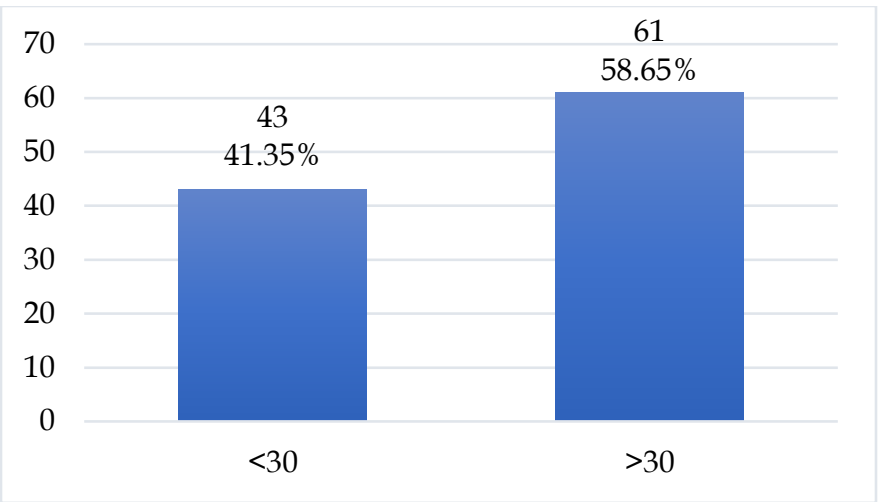

Table 1: Descriptive statistics

\begin{tabular}{|l|c|c|c|}
\hline \multicolumn{1}{|c|}{ Variable } & $\begin{array}{c}\text { Mean } \pm \\
\text { SD }\end{array}$ & $\begin{array}{c}\text { Standard } \\
\text { Deviation }\end{array}$ & $\begin{array}{c}\text { Min- } \\
\text { Max }\end{array}$ \\
\hline Age (Years) & 38.96 & \pm 7.64 & $24-52$ \\
\hline $\begin{array}{l}\text { Duration of disease } \\
\text { (Years) }\end{array}$ & 1.58 & \pm 0.64 & $1-4$ \\
\hline BMI $\left(\mathrm{kg} / \mathrm{m}^{2}\right)$ & 29.78 & \pm 3.33 & $24-33$ \\
\hline Cholesterol $(\mathrm{mg} / \mathrm{dl})$ & 132.19 & \pm 13.29 & $97-159$ \\
\hline Triglycerides $(\mathrm{mg} / \mathrm{dl})$ & 142.25 & \pm 8.71 & $130-159$ \\
\hline LDL $(\mathrm{mg} / \mathrm{dl})$ & 101.87 & \pm 17.57 & $78-138$ \\
\hline HDL $(\mathrm{mg} / \mathrm{dl})$ & 30.43 & \pm 2.56 & $26-34$ \\
\hline
\end{tabular}


Table 2: Stratifications for age, gender, duration of disease and BMI with respect to mean lipid profile

\begin{tabular}{|c|c|c|c|c|c|c|c|c|c|c|c|c|}
\hline \multirow[t]{2}{*}{ Lipid Profile } & \multicolumn{3}{|c|}{ Age in years } & \multicolumn{3}{|c|}{ Gender } & \multicolumn{3}{|c|}{$\begin{array}{c}\text { Duration of disease } \\
\text { (years) }\end{array}$} & \multicolumn{3}{|c|}{ BMI kg/m² } \\
\hline & $21-40$ & $41-60$ & $\begin{array}{c}\mathrm{P}- \\
\text { value }\end{array}$ & Male & Female & $\begin{array}{c}\mathrm{P}- \\
\text { value }\end{array}$ & $\begin{array}{l}\text { More } \\
\text { than } 2\end{array}$ & $\begin{array}{l}\text { Less } \\
\text { than } 2\end{array}$ & $\begin{array}{c}\mathrm{P}- \\
\text { value }\end{array}$ & $<30$ & $>30$ & $\begin{array}{c}\mathrm{P}- \\
\text { value }\end{array}$ \\
\hline Cholesterol & $\begin{array}{r}132.56 \\
+12.89\end{array}$ & $\begin{array}{r}133.47 \\
+14.16\end{array}$ & 0.73 & $\begin{array}{r}133.39 \\
+11.86 \\
\end{array}$ & $\begin{array}{r}131.85 \\
+16.25 \\
\end{array}$ & 0.56 & $\begin{array}{l}127.48 \\
+14.42\end{array}$ & $\begin{array}{l}134.87 \\
+12.56\end{array}$ & 0.23 & $\begin{array}{r}135.00 \\
+15.42 \\
\end{array}$ & $\begin{array}{r}131.51 \\
+11.69\end{array}$ & 0.21 \\
\hline Triglycerides & $\begin{array}{l}142.26 \\
+8.85\end{array}$ & $\begin{array}{l}142.22 \\
+8.62\end{array}$ & 0.84 & $\begin{array}{l}142.31 \\
+9.08\end{array}$ & $\begin{array}{l}142.76 \\
+8.01\end{array}$ & 0.79 & $\begin{array}{l}139.70 \\
+7.39\end{array}$ & $\begin{array}{l}143.43 \\
+8.97\end{array}$ & 0.38 & $\begin{array}{l}144.21 \\
+8.65\end{array}$ & $\begin{array}{l}141.23 \\
+8.61\end{array}$ & 0.08 \\
\hline $\begin{array}{c}\text { Low density } \\
\text { lipids }\end{array}$ & $\begin{array}{r}104.20 \\
+18.08 \\
\end{array}$ & $\begin{array}{c}98.81 \\
+16.60 \\
\end{array}$ & 0.11 & $\begin{array}{r}103.10 \\
+18.47 \\
\end{array}$ & $\begin{array}{r}99.34 \\
+15.53 \\
\end{array}$ & 0.28 & $\begin{array}{r}93.06 \\
+13.18\end{array}$ & $\begin{array}{r}104.96 \\
+17.94 \\
\end{array}$ & 0.02 & $\begin{array}{r}102.42 \\
+12.74\end{array}$ & $\begin{array}{r}101.49 \\
+20.40\end{array}$ & 0.79 \\
\hline $\begin{array}{l}\text { High density } \\
\text { lipids }\end{array}$ & $\begin{array}{l}30.53 \\
+2.56\end{array}$ & $\begin{array}{r}30.29 \\
+2.59\end{array}$ & 0.63 & $\begin{array}{r}30.75 \\
+2.73\end{array}$ & $\begin{array}{r}29.77 \\
+2.07\end{array}$ & 0.06 & $\begin{array}{l}29.58 \\
+2.90\end{array}$ & $\begin{array}{r}30.72 \\
+2.38 \\
\end{array}$ & 0.72 & $\begin{array}{r}30.77 \\
+2.10\end{array}$ & $\begin{array}{r}30.19 \\
+2.83 \\
\end{array}$ & 0.25 \\
\hline
\end{tabular}

\section{DISCUSSION}

Pre-malignant lesions and conditions of the oral mucosa are indicators of risk of likely future malignancies elsewhere in (clinically normal-appearing) oral mucosa and not only site-specific predictors. ${ }^{18}$ Oral submucous fibrosis due to its malignant potential is a clinically significant disease. ${ }^{9-11,22}$ As there is no definitive treatment for Oral sub-mucous fibrosis, thus focus should be placed on prevention, early diagnosis and evaluation of the malignant potential of the disease.

Lipids are cell membrane components essential for various biological functions including growth and division of normal and malignant tissues they are also imperative for the structural and functional integrity of biological membranes. ${ }^{8}$ Declined pattern of serum lipid profile in various cancers is advocated, $7,8,13,21,23$ it is also observed in oral sub-mucous fibrosis. ${ }^{4-10}$ Oral Submucous Fibrosis is associated overexpression of Ki-67 antigen which is marker of cellular proliferation, increase in Bcl2 (anti-apoptotic gene) and overexpression of mutated p53 which are attributing factors toward increased cell proliferation in oral submucous fibrosis at genetic and bio-molecular level. ${ }^{14,16}$ More over pathophysiology of disease is associated with chronic inflammation, tissue hypoxia, increased fibroblast production, increased collagen deposition with progressive fibrosis which is directly associated with increase cell proliferation. ${ }^{12,17}$ Low lipid profile in Oral Submucous Fibrosis and other premalignant conditions is due to increase utilization of lipids as cell membrane component, due to reason of increase cellular proliferation..$^{15}$

Along with above-mentioned trend, there is also decreased serum iron, serum albumin and $\mathrm{Hb}$ levels observed in oral submucous fibrosis patients. ${ }^{18-20}$

There is no predictive lipid profile value given in literature among Oral Submucous Fibrosis patients and its conversion to Oral Squamous Cell carcinoma, only a declining pattern of lipid profile has been concluded.

Main objective of this study was to assess the lipid profile pattern among patients of Oral Submucous Fibrosis, thereby providing a biological marker and prognostic indicator in the early detection of malignant potential of disease. An effort is made to compare these levels among different age groups, genders, BMI and duration of disease.

Results of this study shows a male predilection towards this disease which might be due to reason of easy access of males for tobacco, betel quid and areca nut products which are openly available in markets at an affordable price. Due to social and cultural norms in South-East Asian countries, females are not encouraged for access to these products. Majority of patients were reported to have disease in $2^{\text {nd }}$ and $3^{\text {rd }}$ decade of life, which states that the young population is more affected. These epidemiological results are close to figures given by Ahmad MS et al23 in their study of 157 diagnosed OSMF patients at Patna dental college-India.

In our study, about two third majority of patients reported to have disease duration for more than 2 years, which indicates that patients suffering from OSMF most of time do not tend to acquire medical opinion, unless the disease becomes progressive enough to compromise their routine life activities or painful mouth conditions elicit. Mean LDL value is at a pattern of significant decrease as the duration of disease increase thus it can be inferred that duration of disease has an inverse relation with serum lipids among OSMF patients, which is also supported by Kanthem et al, ${ }^{5}$ who concludes an inverse relation of all lipid panel components with disease progression and duration, but our study results show an inverse change for LDL only. Kumar et $\mathrm{al}^{10}$ in their study also conclude a declining pattern of serum lipid profile but TG and VLDL (very low-density lipids) had no change in pattern, which is similar to our study in which TG has no change in pattern in terms of disease duration, however in our study VLDL are not evaluated.

Mean lipid profile when compared in both genders showed no significant change, even it was not significant in different age groups.

\section{CONCLUSION}

There is no significant alteration when lipid profile change is observed among OSMF patients in terms of their different age groups, gender and BMI. Serum LDL were found to be inversely proportional with duration of disease, which also reflects the severity of disease in terms 
of disease duration at biochemical level, but a detailed study of lipid profile in OSMF patients is required in future, so that more useful facts may be revealed which may lead it to be an important biological marker in diagnosis, prognosis and gauging of the pre-malignant potential of this oral disease condition.

\section{LIMITATIONS}

Lack of control group is a limitation of this study, as this research was conducted at a public sector hospital, thus financial constraints, ethical concerns and consent for taking fasting blood samples from healthy individuals, who have no active complain, were the main reason for not having a control group. Another limitation is lack of clinical staging of OSMF patients in this study, although patients were diagnosed cases of OSMF but they were not staged clinically to determine disease severity.

\section{SUGGESTIONS / RECOMMENDATIONS}

Due to the fact that incidence Oral Submucous Fibrosis is increasing heavily in our local population, further studies should be persuaded in various tertiary care hospitals of Pakistan, thus preventive and therapeutic measures could be formulated at national level.

\section{CONFLICT OF INTEREST / DISCLOSURE}

There was no conflict of interest.

\section{ACKNOWLEDGEMENTS}

We acknowledge hospital administration, our patients, our faculty and colleagues for being so kind and helpful from initial steps of study design to data collection, sampling and consent. It was never possible without team work. I also acknowledge the support and affirmation provided by Dental College HITEC IMS during this study.

\section{REFERENCES}

1. Murti PR, Bhonsle RB, Pindborg JJ, Daftary DK, Gupta PC, Mehta FS. Malignant transformation rate in oral submucous fibrosis over a 17-year period. Community Dent Oral Epidemiol. 1985;13:340-1.

2. Peng Q, Li H, Chen J, Wang Y, Tang Z. Oral submucous fibrosis in Asian countries. J Oral Pathol Med. 2020;49(4):294-304.

3. Hande AH, Chaudhary MS, Gawande MN, Gadbail AR, Zade PR, Bajaj $S$ et al. Oral submucous fibrosis: An enigmatic morphoinsight. J Cancer Res Ther. 2019;15(3):463-9.

4. Gupta S, Gupta S. Alteration of serum lipid profile patterns in oral cancer and oral precancerous lesion and conditions: a clinical study. Indian J Dent. 2011;2(2):1-7.

5. Kanthem RK and Guttikonda VR. Serum lipid profile in oral submucous fibrosis: A clinico pathological study. J Oral Maxillofac Pathol. 2015;19(2):139-44.

6. Anand K, Sudheer A, Chatterjee K. Alteration in serum lipid profile pattern in oral cancer and oral submucous fibrosis patients. J Ind Acad Oral Med Radiol. 2018;30(1):38-40.
7. Patel PS, Shah MH, Jha MH, Raval G, Rawal RM, Patel MM, et al. Alteration in plasma lipid patterns in head and neck cancer and oral precancerous conditions. Indian J Cancer. 2004;41(1):25-31.

8. Pratap M, Sinha A, Srivastav S, Mishra A, Iqbal H. Estimation of serum lipid profile in patients with OSMF. J Ind Acad Oral Med Radiol. 2018;30(2):102-6.

9. Kark JD, Smith AH, Hames CG. Serum retinol and the inverse relationship between serum cholesterol and cancer. Br Med J. 1982;5:152-4.

10. Kumar P, Singh A, Sankhla B, Naraniya A. Alteration in plasma lipid profile in oral submucous fibrosis patients: A case control study. South Asian J Cancer. 2013;2(3):147-9.

11. Haider SM, Merchant AT, Fikree FF, Rahbar MH. Clinical and functional staging of oral submucous fibrosis. Br J Oral Maxillofac Surg. 2000;38(1):12-5.

12. Choudhari SS, Kulkarni DG, Patankar S, Kheur SM, Sarode SC, Sarode GS, Patil S. Angiogenesis and Fibrogenesis in Oral Submucous Fibrosis: A Viewpoint. J Contemp Dent Pract. 2018;19(2):242-5.

13. Reddy AV, Killampalli LK, Prakash AR, Naag S, Sreenath G, Biraggari SK. Analysis of lipid profile in cancer patients, smokers, and nonsmokers. Dent Res J. 2016;13(6):494-9.

14. Arakeri G, Rai KK, Hunasgi S, Merkx MA, Gao S, Brennan PA. Oral submucous fibrosis: an update on current theories of pathogenesis. J Oral Pathol Med. 2017;46(6):406-12.

15. Subbulakshmi AC, Mohan N, Thiruneervannan R, Naveen S. Comparative evaluation of serum lipid profile in patients with oral submucous fibrosis and oral squamous cell carcinoma with that of control subjects: A case control study. J Pharm Bioall Sci. 2017;9(1):191-6.

16. Shih YH, Wang TH, Shieh TM, Tseng YH. Oral submucous fibrosis: a review on etiopathogenesis, diagnosis, and therapy. Int J Mol Sci. 2019;20(12):2940.

17. Ekanayaka RP, Tilakaratne WM. Oral submucous fibrosis: review on mechanisms of malignant transformation. Oral Surg Oral Med Oral Pathol Oral Radiol. 2016;122(2):192-9.

18. Tadakamadla J, Kumar S. Evaluation of serum copper and iron levels in oral submucous fibrosis patients. Med Oral Patol Oral Cir Bucal. 2011;16(7):870-3.

19. Khanna SS, Karjodkar FR. Circulating immune complexes and trace elements (Copper, Iron and Selenium) as markers in oral precancer and cancer : a randomised, controlled clinical trial. Head Face Med. 2006;2:33.

20. Prime SS, MacDonald DG, Rennie JS. The effect of iron deficiency on experimental oral carcinogenesis in the rat. $\mathrm{Br} J$ Cancer.1983;47(3):413-8.

21. Allampallam K, Dutt D, Nair C, Shetty V, Mundle S, Lisak L, et al. The clinical and biologic significance of abnormal lipid profiles in patients with myelodysplastic syndromes. J Hematother Stem Cell Res. 2000;9(2):247-55.

22. Gilbert MS, Ginsberg H, Fagerstrom R, Brown WV. Characterization of hypocholesterolemia in myeloproliferative disease: Relation of disease manifestations and activity. Am J Med. 1981;71(4):595-602.

23. Ahmad MS, Ali SA, Ali AS, Chaubey KK. Epidemiological and etiological study of oral submucous fibrosis among gutkha chewers of Patna, Bihar, India. J Indian Soc Pedod Prev Dent. 2006;24(2):84-9.

24. Web Med, Web MD Medical Reference Reviewed by Michael Dansinger, MD on May 18, 2019 http://webmd.com/cholesterol_management/guide/tests_for_h igh_cholesterol_lipid_panel. 